\title{
Ohlédnutí za Mezinárodním kongresem psychologie ICP 2020+
}

\author{
Jindřiška Kotrlová, Šárka Dobiášová, Veronika A. Polišenská
}

V červenci 2021 se konala jedna z nejvýznamnějších odborných akcí, jejímž pořadatelem byla česká psychologická obec, resp. Českomoravská psychologická společnost společně s dalšími partnery, především se společností Computer System Group a.s. v roli kongresové agentury, a s univerzitními a výzkumnými pracovišti v České republice. Konání Mezinárodního kongresu psychologie pod záštitou International Union of Psychological Science - IUPsyS bylo z důvodu pandemie covid-19 přesunuto $\mathrm{z}$ roku 2020, nicméně ani v roce 2021 situace nedovolila uspořádat tak velkou mezinárodní akci obvyklým prezenčním způsobem. ICP 2020+ proběhl tedy v režimu online s prakticky bezproblémovou realizací, za což patř́ technologickému týmu CSG opravdový dík.

Vrat'me se však do dřivějších časů. Kongres ICP, který je vlakovou lodí mezinárodní psychologické asociace IUPsyS (International Union Psychological Science), se koná od roku 1972 každé čtyři roky. První ročník se konal v Paříži v roce 1889, poté se intervaly pohybovaly v rozmezí 3-5 let, s výjimkou období mezi lety 1909 - Ženeva až 1923 - Oxford, kdy se tento kongres nekonal. Také druhá světová válka způsobila 11letou přestávku (1937 - Paříž a až 1948 - Edinburgh) [1]. Samotná asociace IUPsyS byla založena až v roce 1951 v rámci 13. ICP ve Stockholmu s jedenácti členy, do konce roku 1951 přistoupilo dalších devět zemí [2].

Československá psychologická společnost se stala členem IUPsyS v roce 1963 (5 let po obnovení činnosti v rámci ČSAV). O členství pak přišla rozdělením státu v roce 1993. Na tomto místě je třeba připomenout zásluhu prof. Josefa Švancary, který se v roce 1996 jako člen Rady ČMPS na vlastní náklady účastnil ICP v Montrealu, vysvětlil vedení IUPsyS naši situaci a vyjednal obnovu členství pro Českomoravskou psychologickou společnost jako reprezentanta České republiky od téhož roku.

Právo ucházet se o pořadatelství ICP má každá členská národní asociace. Po úspěšném uspořádání mezinárodních kongresů EAWOP 2001 (ČAPPO), IAREP 2005 (ČAPPO) a ECP 2007 (UPA ČR) v Praze přišel PhDr. Miloslav Šolc, předseda ČAPPO, v roce 2011 - tedy před deseti lety - s myšlenkou ucházet se o ICP 2020. Byl to nejbližší volný termín a hlasování o pořadatelství bylo naplánováno v rámci ICP 2012 v Kapském Městě (o ICP 2016 bylo již rozhodnuto z roku 2008 v Berlíně). Dopis o projevení zájmu (Letter of Intent) byl zaslán vedení IUPsyS 18. července 2011 a podepsán tehdejším předsedou ČMPS PhDr. Jaroslavem Šturmou a předsedkyní Unie psychologických asociací ČR PhDr. Janou Zapletalovou.

V pracovní skupině, připravující kandidaturu ČR pro ICP 2020, byli Miloslav Šolc, Jiří Kirchner a Martina Klicperová [3]. V průběhu jara 2012 byla zpracována nabídka pořadatelství ICP 2020 a odeslána generálnímu sekretáři IUPsyS. Předsedou př́pravného výboru byl prof. Stanislav Štech, dalšími členy byli: PhDr. Jaroslav Šturma, prof. Marek Blatný, Veronika Polišenská, Ph.D., PhDr. Miloslav Šolc a prof. Jaromír Janoušek [4]. Mezinárodní kongres ICP 2012 se konal v jihoafrickém Kapském Městě ve dnech 22. - 27. července. 
V rámci kongresu se již tradičně konalo Valné shromáždění IUPsyS, sestávající z 74 delegátů reprezentujících 47 členských asociací.

ČMPS zastupoval dr. Jaroslav Šturma a dr. Miloslav Šolc, další členové týmu měli statut pozorovatele: Martina Klicperová, Petr Kavalî́r, Jiř́i Kirchner a Šárka Dobiášová s Vladimírem Votápkem z CSG [5]. Martina Klicperová ve zprávě z kongresu napsala:

„Do soutěže o pořadatelství pro rok 2020 byla přihlášena dvě města - favorizovaný Řím a Praha. S přibližujícím se dnem voleb se ale začaly vážky šancí zřetelně vyrovnávat. Český tým, vedený zkušeným M. Šolcem, přijel totiž na klání s Římem skvěle připraven a posílen o kongresové organizátory z pražské Computer System Group (CSG). Na odhodlání Prahy utkat se o organizování ICP 2020 tak byli řadoví účastníci kongresu i volitelé už od počátku předem upozorňováni pomocí letáčků, plakátů, kuloárových jednání, banketu s osobní účastí velvyslankyně Blanky Fajkusové, a konečně také oficiálním přednesením pražské nabídky na Valném shromáždění. Součástí této nabídky byla pečlivě zpracovaná brožura a také dramaticky pojatý dialog s projekcí, ve kterém psycholožka a inženýr seznámili publikum s vizí pražského kongresu. Scénka i profesionálně připravené podklady vzbudily velký ohlas, výroky ,Zdá se, že jste připraveni kongres uspořádat už zítra!“” a hlavně jednoznačné vítězství Prahy.“ [6].

Do konce července 2012 přišlo z IUPsyS potvrzení o schválení pořadatelství ICP v roce 2020. Vedení IUPsyS současně oznámilo čtyřdenní pracovní návštěvu Prahy na prosinec 2012. V rámci této první návštěvy proběhla řada jednání zaměřených na př́ípravu kongresu, prohlídka možných kongresových prostor (část Kongresového centra Praha byla $\mathrm{v}$ té době zrovna v rekonstrukci, takže prohlídka byla poněkud dobrodružná) i neformální rozhovory.

Další návštěvy zástupců IUPsyS se uskutečnily na podzim 2013 a 2014. Od podzimu 2014 začala jednání o smlouvě mezi IUPsyS a ČMPS, jež byla pak podepsána v dubnu 2016. Jednou $\mathrm{z}$ podmínek smlouvy bylo, že pořadatelé se budou účastnit všech větších psychologických kongresů ve světě a oslovovat zde potenciální účastníky. Počínaje rokem 2015 byl tedy ICP 2020 propagován na kongresech EFPA v Miláně (2015), Amsterdamu (2017) a v Moskvě (2019), na ICP 2016 v Jokohamě, na kongresu IAAP v Montrealu 2018, na APA Convention 2019 v Chicagu a řadě dalších. ICP 2016 v Jokohamě byl zvlášt' důležitý, nebot' tehdejší předseda ČMPS PhDr. Daniel Heller oficiálně podepsal a slavnostně převzal od prezidenta kongresu K. Shigemasu pořadatelství ICP do Prahy (obr. 1). V průběhu kongresu se již tradičně konalo Valné shromáždění IUPsyS, kde byla zvolena novou členkou EC IUPsyS Martina Klicperová [7].

Nelze nezmínit jednu ze smutných událostí ze záŕí 2016, kdy zemřel PhDr. Miloslav Šolc, iniciátor ICP 2020 v Praze. Jeho odchod všechny zaskočil a byl pro ostatní organizátory opravdovou ztrátou.

Od jara 2017 pracoval organizační výbor (OV) ve složení: Stanislav Štech, Šárka Dobiášová, Martina Klicperová, Iva Poláčková Šolcová, Veronika Polišenská, Daniel Heller, Šárka de Groot, Jindřiška Kotrlová. Vedle zajištění propagace, jejíž náklady nesla převážně CSG, se OV zpočátku věnoval sestavení národního vědeckého výboru (VV) a oslovování hlavních řečníků ze různých kontinentů. Pomocnou rukou byl i nominovaný mezinárodní Advisory Board, jehož OV oslovil ke spolupráci. 
V červnu 2017 se konala v Praze první schůzka VV, kde byl projekt kongresu představen a př́tomní diskutovali o návrhu Pracovních skupin vědeckého výboru dle jednotlivých témat psychologie. Předsedkyní VV byla zvolena Martina Klicperová, místopředsedkyní Veronika Polišenská.

Úloha národního vědeckého výboru a jeho 46 pracovních skupin byla nezastupitelná. Pro web kongresu byly v pracovních skupinách vytvořeny anotace jednotlivých témat pracovních skupin, s jmenovitým uvedením členů. Tito členové nominovali významné kolegy a kolegyně ve své specializaci pro hlavní přednášky, oslovovali další zahraniční kolegy a kolegyně $\mathrm{s}$ výzvou $\mathrm{k}$ účasti. Velmi důležitou rolí bylo vícekolové hodnocení abstraktů, které probíhalo od dubna 2019 do ledna 2020. Celkově bylo v této etapě ohodnoceno k 8000 abstrakt.

Koncem února 2020 se ukazovalo, že konání kongresu v Praze může být ohroženo. WHO vyhlásila 30. ledna globální stav zdravotní nouze, což ovlivnilo v tu dobu zejména cestování. V den vyhlášení nouzového stavu v ČR, 12. března, se online sešel organizační výbor a po delší diskusi rozhodl požádat EC IUPsyS o souhlas s posunutím kongresu na rok 2021. Bylo to těžké rozhodování, ale čas ukázal, že bylo rozumné a zodpovědné. 19. března byla odeslána všem registrovaným účastníkům zpráva o přesunu a novém datu konání v roce 2021 [znění zprávy] a o týden později informace $k$ dosavadním registracím. Nastala situace, se kterou opravdu nikdo nepočítal. Přesun kongresu měl za následek řadu zrušených aktivních účastí, bylo nutné vyřizovat požadavky na vrácení poplatku, odpovídat na e-mailové dotazy, vysvětlovat. V polovině června 2020 byla opět spuštěna registrace abstraktů s tím, že schválené a neodhlášené abstrakty v systému zůstaly jako platné. Bylo velmi oceněníhodné, že kolegové a kolegyně v pracovních skupinách byli i nadále ochotní nová abstrakta posuzovat, i přes svou pracovní zátěž, kterou změněné pracovní podmínky v pandemii covid-19 přinesly. Za to jim patří velký dík.

Bohužel, ani začátek roku 2021 nebyl z hlediska pandemie nijak př́znivý. Stále platila řada omezení a situace se $\mathrm{v}$ různých zemí světa měnila, nedalo se prakticky nic spolehlivě plánovat. Po dohodě s vedením IUPsyS bylo koncem ledna oznámeno, že kongres bude mít poprvé ve své historii - hybridní formát. Registrovaným účastníkům byla umožněna změna, současně zůstávala otevřena registrace pro pasivní účastníky. 11. června však již nezbývalo nic jiného než oznámit, že se celý kongres plně převádí do online podoby.

Rámec online formy tvořila aplikace, umožňující vedle přehledného a prohledavatelného odborného programu i "sociální" funkce - navazování komunikace navzájem, organizaci schůzek, chat u přednášek v reálném čase, vkládání vlastních fotografií atp.

Vědecký program se pak odehrával v několika formátech - šlo o předtočené prezentace účastníků, které bylo možné si v aplikaci průběžně spouštět (a to jak přednášky, tak posterové prezentace), tematické sekce a sympozia $\mathrm{v}$ reálném čase $\mathrm{s}$ moderátorem, který byl v kongresovém studiu př́tomen fyzicky a přednášející se připojovali, kulatý stůl v reálném čase. Kongres si v i těchto podmínkách uchoval obvyklou strukturu: State-of-the-Art Lectures; Keynote Addresses; Invited Symposia; Round Tables; Workshops; Rapid Communication Poster.

Samostatnou kapitolou byl Emerging Psychologists Programme - program pro začínající psychology. Cílem programu je posilovat komunikaci mezi začínajícími psychology z různých zemí a různých kulturních prostředí, podporovat výměnu poznatků mezi zkušenými a mladými 
vědci a pomoci získávat nové poznatky v konkrétních oblastech psychologie. Pro EPP 2020+ bylo vybráno 41 začínajících psychologů (obvykle v doktorském studiu) z celého světa, kteří si navzájem sdíleli svůj výzkum a v rámci online setkání jej diskutovali. Pevně stanovený a strukturovaný program EPP probíhal od ledna 2020 do července 2021. Vedení programu se zodpovědně zhostila doc. PhDr. Irena Smetáčková, Ph.D.

Kongres ICP 2020+ byl zahájen 18. 7. v 17 hod. úvodním vtipným videospotem, v němž v rychlém sledu defilovala hostitelská města kongresu od roku 1889 až po Prahu včetně převedení do virtuálního formátu. V následujícím zahajovacím ceremoniálu promluvila prezidentka IUPsyS Pam Maras a prezident ICP 2020+ Stanislav Štech. Prof. Milada Polišenská promluvila o historii vědy a vzdělávání ve středoevropském kontextu (obr. 3). Součástí ceremoniálu byl záznam symfonie Má vlast v provedení České filharmonie a záznam koncertu dětského folklorního souboru Valášek.

V následujících dnech až do pátku 23. 7. bylo možné virtuálně sledovat odborný program, a to živě i ze záznamu. Program byl přizpůsoben 3 časovým pásmům, začínal v 5 hod. ráno a končil před půlnocí SEČ. Př́ijemným zážitkem byly ranní koncerty, v průběhu odborného programu byly zařazeny také komentované virtuální prohlídky Prahy a streamovaná neformální setkání, tzv. Virtual Café s osobnostmi či možnost vaření českých jídel.

Kongresu se účastnili vědci ze 107 zemí. Zaznělo 19 přednášek State-of-Art, 112 přednášek klíčových řečníků (Keynote addresses), proběhlo na 60 sympozií, 10 kulatých stolů (Round tables) a 6 workshopů, celkově s 3840 účastníky. Technologicky náročná akce proběhla bez problémů díky systémovým ochranám, zálohování napájení a konektivity atp. [8]. Nelze opomenout finanční stránku - kongres měl svůj rozpočet jako součást smlouvy s IUPsyS, každoročně byl aktualizován a schvalován. Vzhledem k nutným změnám s ohledem na pandemickou situaci však neskončil se ziskem, jak se původně očekávalo. I když se některé plánované výdaje v závěru př́prav nerealizovaly, př́ijmy dle finanční zprávy CSG zdaleka nedosáhly očekávaných čísel.

Kongres ICP 2020+ měl to štěstí, že i přes nepř́znivou situaci v závěru př́íprav (anebo možná právě proto) jeho organizační ani vědecký tým nepolevil, dobře a efektivně navzájem spolupracoval a že měl po celou dobu laskavé i inspirativní vedení Martiny Klicperové a Stanislava Štecha, Sathse Coopera a Ann D. Watts, posléze i Pam Maras a. I díky tomuto nasazení se podařilo překonat hned několik rekordů. ICP 2020+ se zapsalo do historie s nejvyšším počtem přednášek State-of-the-Art, s největším počtem účastnických zemí a zároveň se zatím jedná o jediný kongres v historii, který byl během prŕíprav plánován postupně ve třech možných formátech.

I přes všechny výzvy, které musel organizační výbor řešit, byl ICP 2020+ v mnohém ohledu opravdu jedinečný, ukázal nové možnosti, přesto věříme, že v dalším ICP bude možné se vrátit k tomu, co je pro člověka nezbytné, a to k osobnímu setkávání. V závěru děkujeme všem členům vědeckého a organizačního výboru, týmu CSG a dalším zúčastněným. 


\section{(C) PSYCHOLOGIE}

Obrazová př́iloha

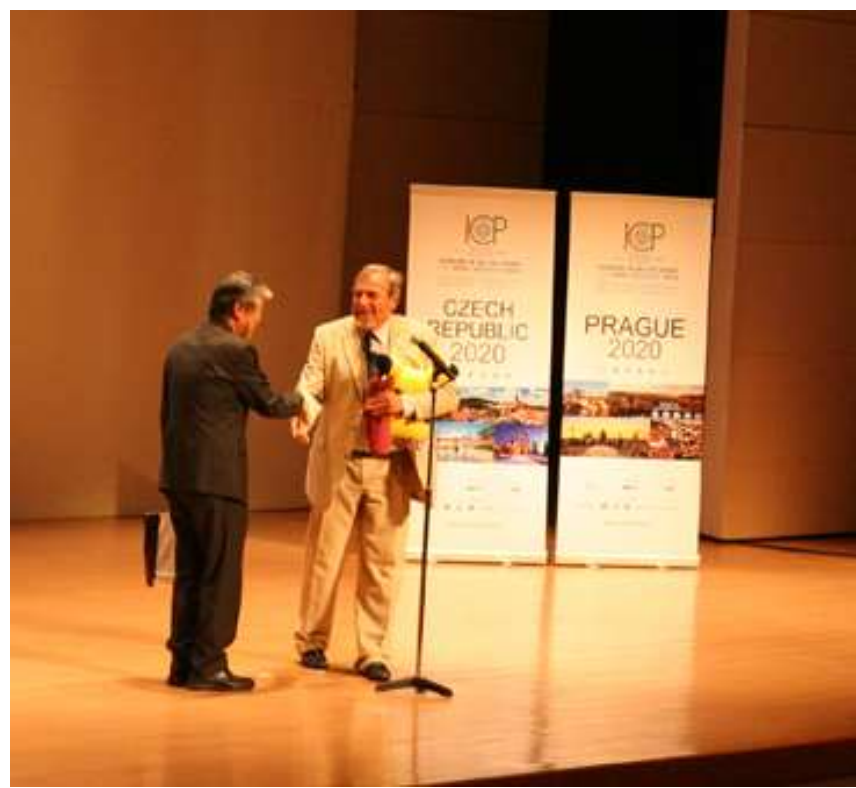

Obr. 1 Dr. Daniel Heller přebírá

pořadatelskou štafetu pro Prahu 2020.

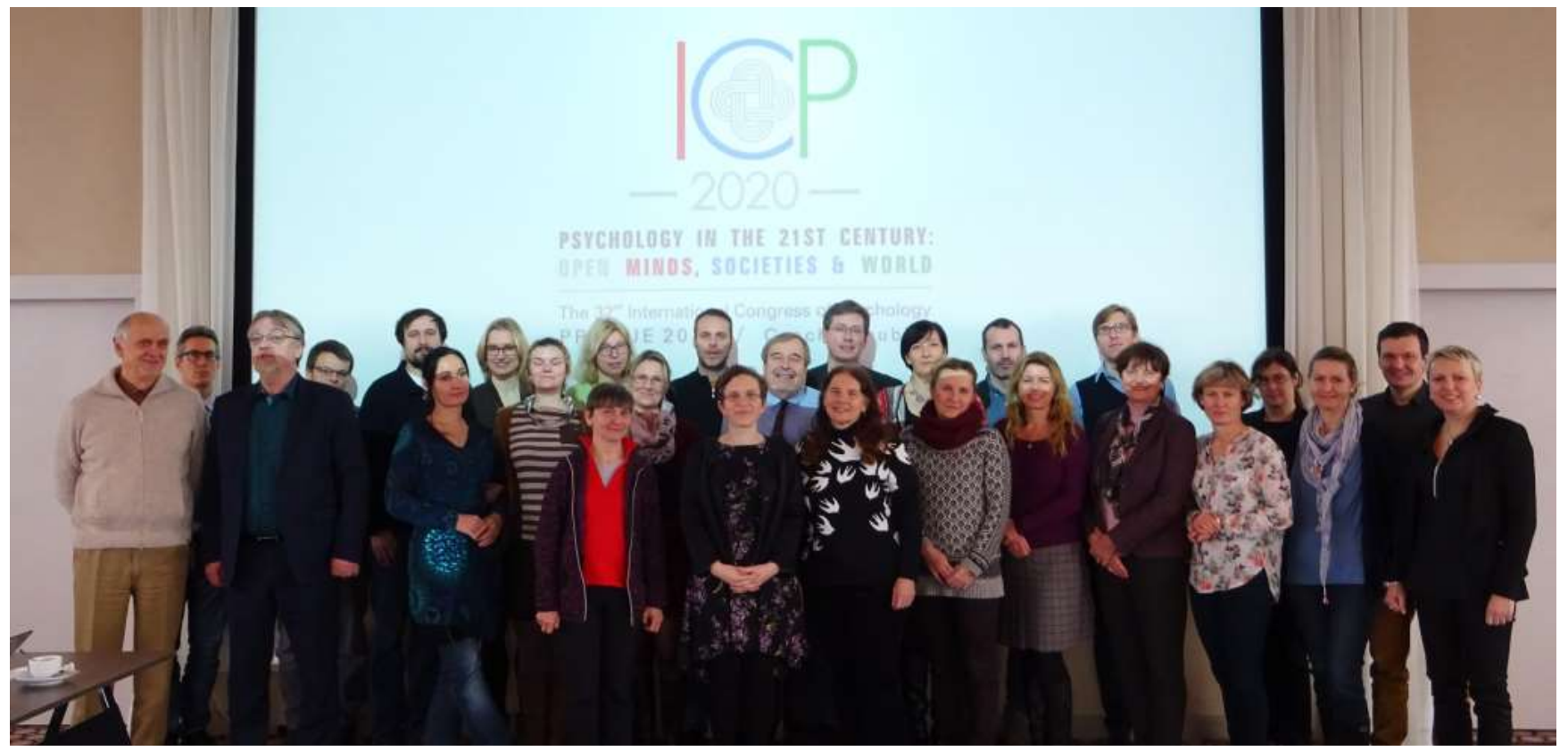

Obr. 2 Vědecký výbor ICP 2020, 28. 1. 2018 


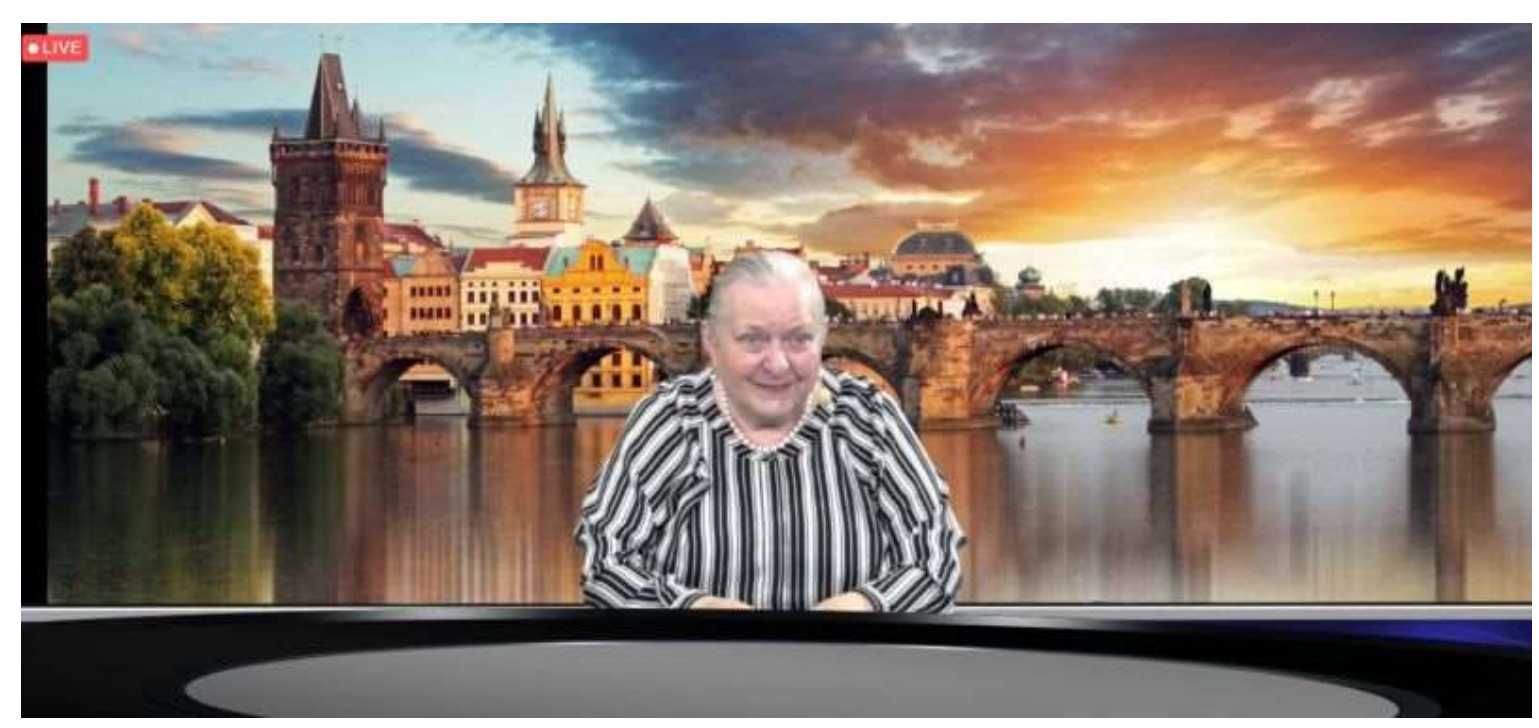

Obr. 3 Prof. PhDr. Milada Polišenská, CSc., Anglo-American University

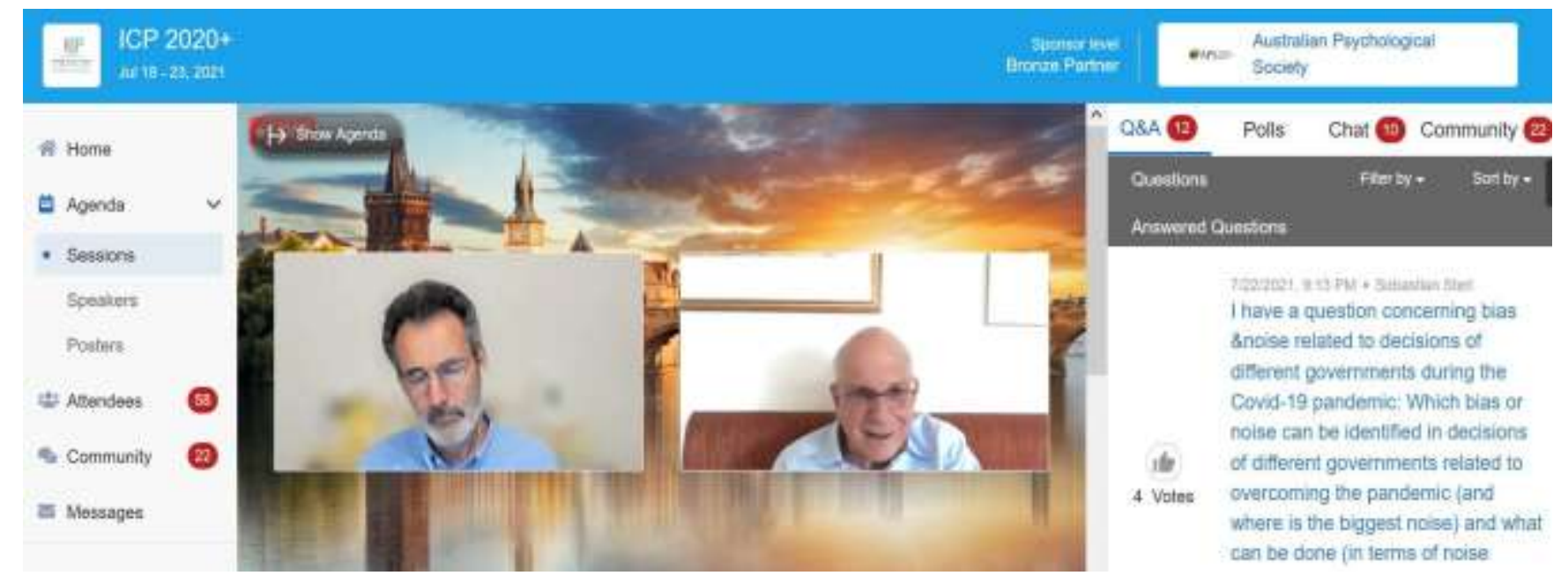

Obr. 4 Přednáška Daniela Kahnemana, moderuje Olivier Sibony 


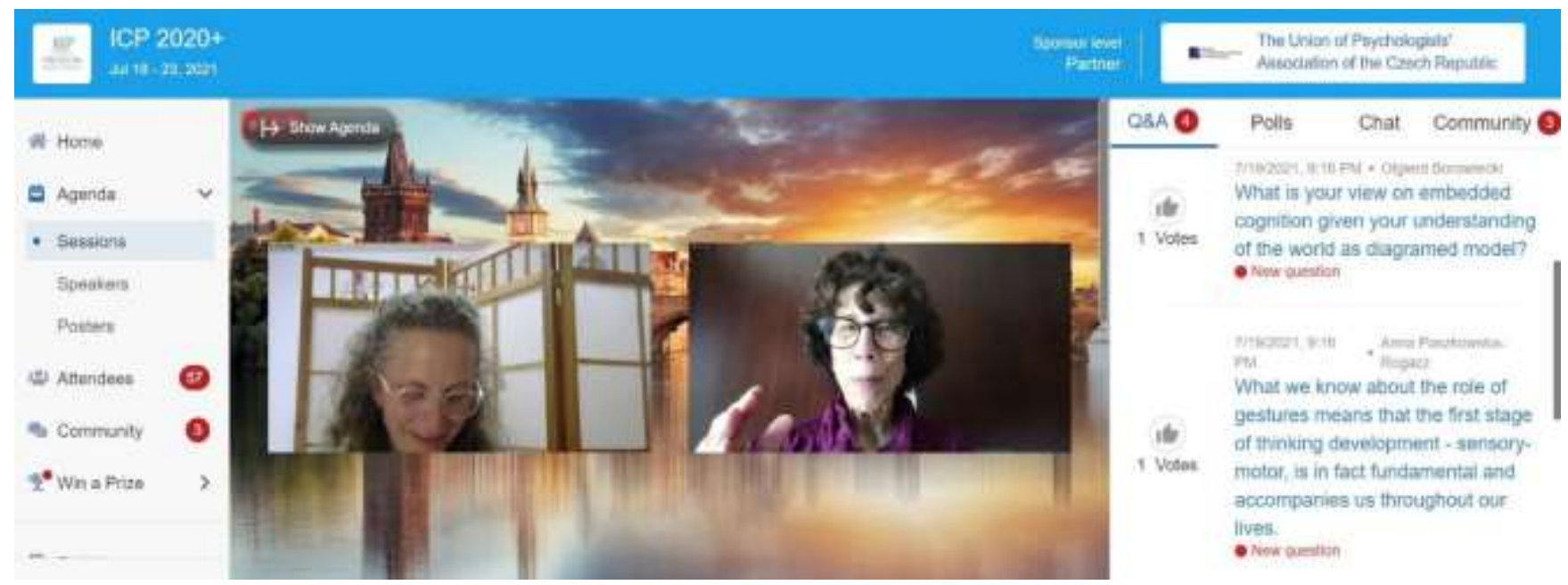

Obr. 5 Přednáška Barbary Tversky, moderuje Veronika Polišenská

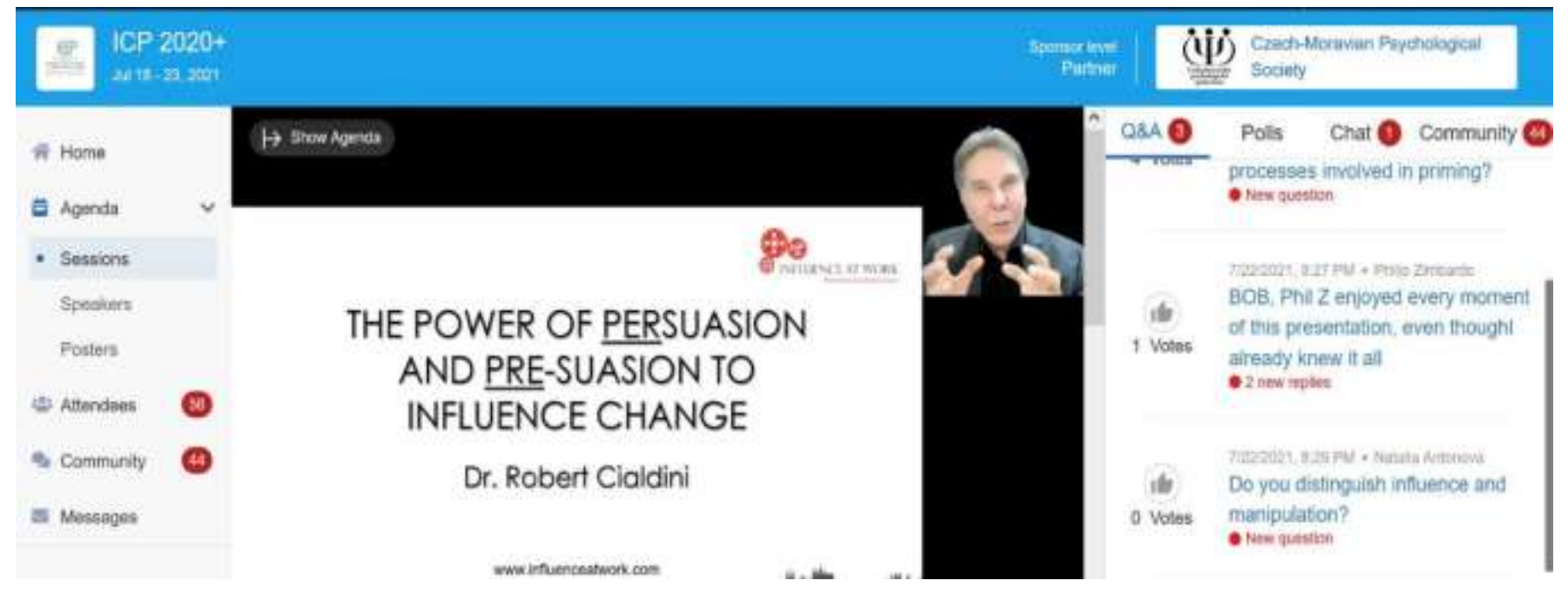

Obr. 6 Přednáška Roberta Cialdiniho

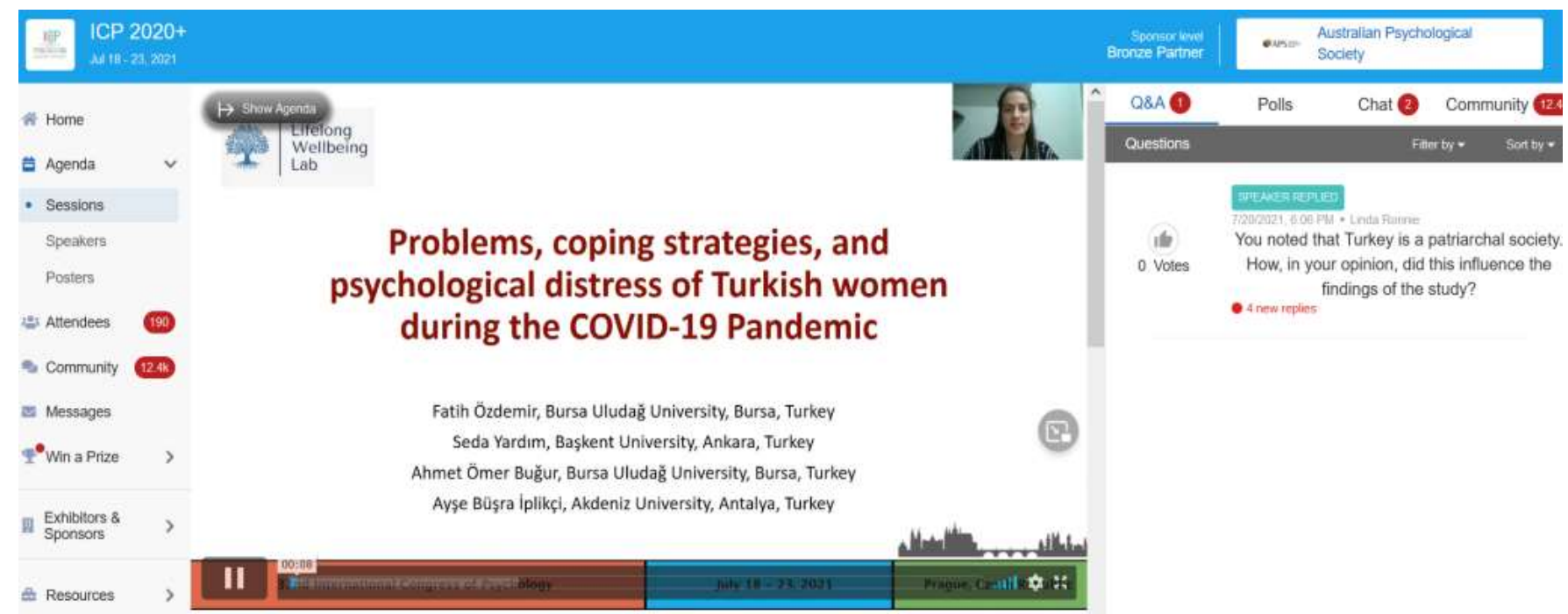

Obr. 7 Přednáška Fatih Özdemir et al. 


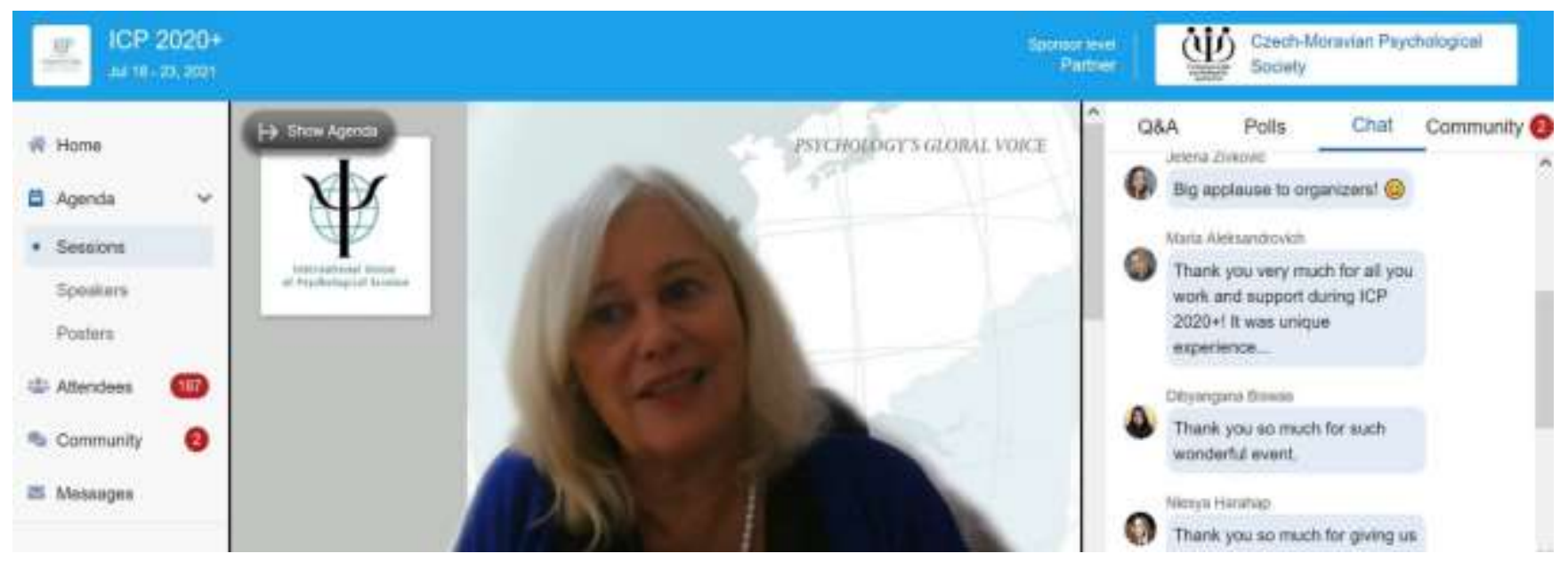

Obr. 8 Prezidentka IUPsyS Pam Maras v Closing Ceremony

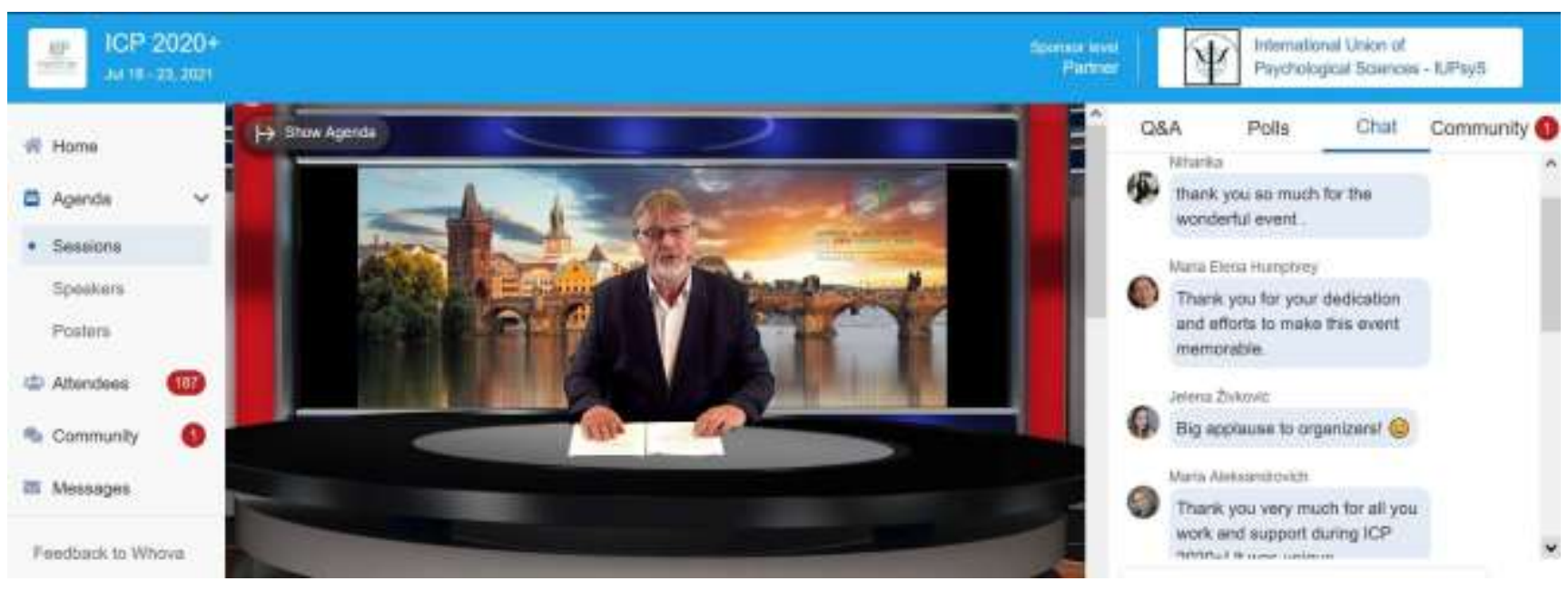

Obr. 9 Prezident ICP 2020+ Stanislav Štech

\section{Zdroje}

[1] IUPsyS. Sites and Years of International Congresses of Psychology.

https://www.iupsys.net/events/international-congress-of-psychology/sites-and-years-ofinternational-congresses-of-psychology/

[2] IUPsyS. IUPsyS History. https://www.iupsys.net/about/iupsys-history/

[3] Rada ČMPS. (19. 4. 2012). Zápis z jednání. Archiv ČMPS. 
[4] Psychology in the 21st Century: Open Minds, Societies \& World. 2012. [Nabídka pořadatelství ICP 2020, brožura s CD].

[5] IUPsyS. Meeting of the IUPsyS Assembly, Cape Town, July 23 \& 25, 2012: Draft Minutes. https://www.iupsys.net/wp-content/uploads/2021/09/minutes-of-2012-assembly-draft.pdf

[6] Klicperová, M. (2012). Mezinárodní psychologický kongres IUPsyS - nečekaný úspěch České republiky v soutěži pořadatelů a výzva pro české psychology. Československá psychologie, 56(5), 500-501.

[7] Klicperová, M. (2016). Česká psychologie na mezinárodním fóru. Československá psychologie, 60(5), 545-546.

[8] ICP 2020+ Team. (August 2021). Against the odds, ICP2021+ succeeded. https://www.icp2020.com/wp-content/uploads/2021/11/ICP-2020-Team-Message.pdf

\section{Videa k ICP 2020+}

ICP 2020+ President Message. 19. 7. 2020.

https://www.youtube.com/watch?v=M-0mvZ-BL2M

ICP 2020+ Interview with Pamela Maras, President of the International Union of Psychological Science. 15. 4. 2021

https://www.youtube.com/watch?v=9Xe2tZyfAKE

ICP 2020+ Interview with the President of ICP 2020+ Stanislav Stech. 6. 5. 2021.

https://www.youtube.com/watch?v=1YmrDW1A10c

ICP 2020+ - Interview with Martina Klicperová-Baker, The Chair of the Scientific Committee. 11. 4. 2021

https://www.youtube.com/watch?v=ZvLNuxZVjnI

ICP 2020+ Invitation from Štěpán Vymětal - The Chair of Psychology of Crises, Trauma and Disaster. 6. 5. 2021.

https://www.youtube.com/watch?v=5JhdOWQwYKU

ICP 2020+ Interview with Co-chairs Psychology of Crises, Trauma and Disaster. 6. 5. 2021. https://www.youtube.com/watch?v=SrHTilQRiCo

ICP 2020+ Invitation from Michal Pitoňák. 6. 5. 2021.

https://www.youtube.com/watch?v=uruP0yv76V0 


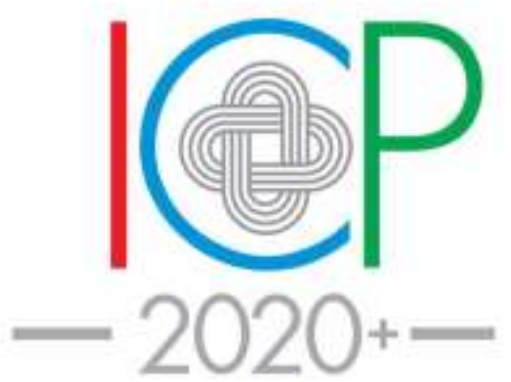

PSYCHOLOGY IN THE 21ST CENTURY: OPEN MINDS, SOCIETIES \& WORLD

The $32^{\text {nd }}$ International Congress of Psychology PRAGUE 2021 / Czech Republic

\section{Údaje o autorkách}

PhDr. Jindřiška Kotrlová pracuje od roku 1994 pro Českomoravskou psychologickou společnost, z.s., od roku 2014 také v Anglo-americké vysoké škole, z.ú. Je spoluzakladatelkou časopisu E-psychologie. V rámci př́prav ICP 2020+ pracovala v organizačním výboru a ve finanční komisi.

E-mail: cmps@ecn.cz

Mgr. et Mgr. Šárka Dobiášová vystudovala psychologii na FF UK, zaměřuje se na psychologii práce a organizace a je současnou předsedkyní České asociace psychologie práce a organizace, z.s. V rámci prŕprav ICP 2020+ zastupovala kongresovou agenturu Computer System Group, byla generální sekretářkou kongresu.

E-mail: sarka.dobiasova@ computersystem.cz

PhDr. Veronika A. Polišenská, Ph.D. se zaměřuje na forenzní psychologii, vyučuje na Vysoké škole finanční a správní. V letech 2007 až 2015 byla členkou Výkonné rady EFPA a členkou organizačního výboru ECP 2007 v Praze. Od roku 2014 je výkonnou místopředsedkyní Unie psychologických asociací ČR. V rámci prŕprav ICP 2020+ pracovala jako místopředsedkyně národního vědeckého výboru.

E-mail: v.polisen@gmail.com

Kotrlová, J., Dobiášová, Š., \& Polišenská, V. A. (2021). Ohlédnutí za Mezinárodním kongresem psychologie ICP 2020+. E-psychologie, 15(4), 69-78. https://doi.org/10.29364/epsy.422 